\title{
Epinastine (WAL 801CL) inhibits the electrical field stimulation-induced cholinergic contraction in guinea pig and human airways in vitro
}

\author{
L.J. Dupont*, J.L. Pype*, C.J. Meade ${ }^{+}$, P. DeLeyn**, G. Deneffe**, M.G. Demedts*, G.M. Verleden*
}

Epinastine (WAL 801CL) inhibits the electrical field stimulation-induced cholinergic contraction in guinea pig and human airways in vitro. L.J. Dupont, J.L. Pype, C.J. Meade, P. DeLeyn, G. Deneffe, M.G. Demedts, G.M. Verleden. (C) ERS Journals Ltd 1999.

ABSTRACT: Epinastine is an antihistamine drug with binding affinities at 5-hydroxytryptamine (5-HT) receptors. The current study was performed to investigate whether epinastine could modulate the cholinergic contraction in guinea pig and human airways in vitro.

Isolated guinea pig and human airway preparations were suspended in organ baths containing modified Krebs-Henseleit solution. Electrical field stimulation was applied to elicit cholinergic contractions.

Epinastine produced a concentration-dependent inhibition of the cholinergic contraction in guinea pig airways and pretreatment with methysergide $\left(5-\mathrm{HT}_{1 / 2 / 7}\right.$ antagonist) significantly attenuated these inhibitory effects of epinastine. Pretreatment with tropisetron (5-HT ${ }_{3 / 4}$ antagonist), ketanserin (5-HT2 antagonist), SDZ216-525 (5$\mathrm{HT}_{1 \mathrm{~A}}$ antagonist) or phentolamine ( $\alpha$-adrenergic antagonist) had no effect. Epinastine did not displace the concentration-response curve to acetylcholine.

These results suggest that epinastine inhibits the cholinergic contraction in guinea pig airways through stimulation of prejunctional 5-hydroxytryptamine receptors, located to postganglionic cholinergic nerves. Inhibitory effects of epinastine on the cholinergic contraction in human airways in vitro were also demonstrated, which suggests that a similar mechanism might be present in human airways. The pharmacological profile of epinastine, which shows binding affinity at the 5-hydroxytryptamine ${ }_{7}$ receptor but not at the 5-hydroxytryptamine $_{1}$ receptor subtypes corroborates the hypothesis that the inhibitory prejunctional 5-hydroxytryptamine receptor on cholinergic nerves is of the 5-hydroxytryptamine 7 subtype.

Eur Respir J 1999; 14: 1068-1075.
*Laboratory of Pneumology, Pulmonary Pharmacology Unit and **Dept of Thoracic Surgery, University Hospital Gasthuisberg, Katholieke Universiteit Leuven, Belgium ${ }^{+}$Boehringer Ingelheim Pharma $\mathrm{KG}$, Ingelheim am Rhein, Germany.

Correspondence: G.M. Verleden Laboratory of Pneumology KUL Campus Gasthuisberg O/N

Herestraat 49

B-3000 Leuven

Belgium

Fax: 3216346803

Keywords: Cholinergic contraction epinastine

guinea pig airways

human airways

5-hydroxytryptamine receptor

Received: June 181998

Accepted after revision June 201999

L.J. Dupont is supported by the faculty of Medicine, Katholieke Universiteit Leuven, J.L. Pype is supported by a grant from GlaxoWellcome, Belgium, G.M. Verleden is holder of the "GlaxoWelcome leerstoel voor respiratoire farmacologie" at the Katholieke Universiteit Leuven, Belgium.
Cholinergic nerves are the dominant neural bronchoconstrictor pathways in both animal and human airways. Many different prejunctional receptors modulate the cholinergic neurotransmission at the level of the postganglionic nerve terminals, among them several receptors for inflammatory mediators [1]. In the present study, the authors have investigated the effects of epinastine (WAL 801CL, Alesion $\AA$, CAS 108929-04-0), a tetracyclic guanidine, on the cholinergic contraction in vitro.

Epinastine was originally developed as an antihistamine drug without sedative side effects on the central nervous system, intended for the treatment of allergic disorders such as asthma [2]. It binds the histamine $(\mathrm{H})_{1}$ receptor with a high affinity and selectivity and its antihistamine properties have been demonstrated in several studies [3]. Oral administration of epinastine, for instance, prevented the bronchoconstriction to inhalation and intravenous administration of histamine in guinea pigs [3-5]. Bronchospasmolytic effects of epinastine after histamine inhalation have also been demonstrated in humans [2]. Pharmacological studies have further identified epinastine as a 5hydroxytryptamine $(\mathrm{HT})_{2}$ antagonist, probably due to its structural resemblance to other guanidines that have been shown to be peripherally acting $5-\mathrm{HT}_{2}$ antagonists [6].

Other properties of this drug are less well characterized. Epinastine shows some binding affinity at the $\alpha_{2}$-adrenergic receptor [3]. Bronchoconstriction induced by platelet activating factor (PAF) in guinea pigs was attenuated by pretreatment with epinastine [4]. Intravenous administration of epinastine in anaesthetized guinea pigs protected against bradykinin-induced bronchoconstriction [4]. However, there was no effect of epinastine on the bronchoconstriction induced by endothelin-1, prostaglandin $\mathrm{D}_{2}$, leukotriene $\mathrm{D}_{4}$, substance $\mathrm{P}$ and neurokinin $\mathrm{A}$ in guinea pigs [5]. The underlying mechanism of the inhibitory effects of epinastine on allergen-, PAF- and bradykinin-induced hyperresponsiveness has not been further elucidated. Epinastine also protected rats from bronchoconstriction induced by $N^{6}$-2-(4-aminophenyl)ethyladenosine (APNEA), possibly through a neurally mediated mechanism [7].

It has also been demonstrated that the nonadrenergic, noncholinergic (NANC) contraction, mediated by the release of neuropeptides from sensory nerves, in guinea pig 
airways was significantly inhibited by epinastine [8], through stimulation of a prejunctional 5-HT receptor. The 5-HT receptor subtype that mediates the effects of epinastine was originally described as a 5 - $\mathrm{HT}_{1}$-like receptor subtype [9] similar to the orphan 5-HT receptors that mediate smooth muscle relaxation in a variety of tissues. The pharmacological profile of this receptor, however, now fits the operational profile of a $5-\mathrm{HT}_{7}$ receptor [10].

The aim of the present study was to investigate whether epinastine could modulate the cholinergic contraction elicited by electrical field stimulation (EFS) in both guinea pig and human airways in vitro.

\section{Methodology}

\section{Tissue preparation}

Dunkin-Hartley guinea pigs of either sex (300-600 g) were killed by cervical dislocation. The trachea was removmoved, cut in segments containing four to five cartilaginous rings and placed in carbogenated modified Krebs-Henseleit $(\mathrm{KH})$ solution of the following composition (in millimoles per litre): $\mathrm{NaCl}, 118 ; \mathrm{MgSO}_{4}, 1.2 ; \mathrm{KCl}, 5.9 ; \mathrm{CaCl}_{2}$, 2.5; $\mathrm{NaH}_{2} \mathrm{PO}_{4}, 1.2 ; \mathrm{NaHCO}_{3}, 25.5$; and glucose, $5.05(\mathrm{pH}$ 7.4). Macroscopically normal human bronchial tissue was obtained from thoracotomy specimens of patients (2 females, 12 males; age mean \pm SEM $67 \pm 8$ yrs) undergoing surgery for bronchial carcinoma. Guinea pig airway strips or human bronchial ring segments were prepared as described previously $[8,9,11]$, and were mounted vertically between two platinum wire electrodes in $10 \mathrm{~mL}$ organ baths containing modified $\mathrm{KH}$ solution, which was maintained at $37^{\circ} \mathrm{C}$ and continuously bubbled with $5 \% \mathrm{CO}_{2}$ in $\mathrm{O}_{2}$. The preparations contracted against a load of $1 \mathrm{~g}$ for guinea pig tissue and $2 \mathrm{~g}$ for human tissue. While being washed with fresh KH solution every $20 \mathrm{~min}$, tissues were allowed to equilibrate under tension for at least $60 \mathrm{~min}$ before beginning experimental protocols, during which time a stable baseline tension was achieved. All experiments were performed in the presence of indomethacin $(10 \mu \mathrm{M})$ to prevent modulation of neural responses by endogenously synthesized prostaglandins [12].

\section{Experimental protocol}

Isometric contractile responses, induced either by EFS or by adding acetylcholine (ACh), were measured by using a Grass FT 03 force-displacement transducer (STAG instruments Ltd., Chalgrove, Oxon, UK). The traces were visualized on a computer screen after digitalization of the signal (Codas; Dataq Instrument Inc., Akron, OH, USA) and recorded on a personal computer.

Electrical field stimulation. EFS was produced by a Harvard student stimulator (Harvard Apparatus Ltd., Edenbridge, Kent, UK). Biphasic square-wave pulses of a supramaximal voltage of $50 \mathrm{~V}$ at source and a pulse duration of $0.5 \mathrm{~ms}$ were delivered for $15 \mathrm{~s}$ every $4 \mathrm{~min}$ at frequencies ranging $0.5-32 \mathrm{~Hz}$ in guinea pig airways and $1-32 \mathrm{~Hz}$ in human airways. In both guinea pig and human preparations EFS caused a rapid and transient contraction that was abolished by pretreatment of the tissues with atropine, confirming that the contractile res- ponses were due to the release of $\mathrm{ACh}$. Hexamethonium $(10 \mu \mathrm{M})$, a ganglion blocker, had no effect on the cholinergic contraction elicited by EFS, which confirms that the contractile responses were mediated by the release of ACh from postganglionic cholinergic nerves. The responses to EFS were completely blocked by the fast $\mathrm{Na}^{+}$-channel blocker tetrodotoxin $(1 \mu \mathrm{M})$ confirming their neuronal origin. Tissues that exhibited a potent NANC contraction in addition to the cholinergic contraction were discarded.

After the equilibration period a frequency-response curve (FRC) $(0.5-32 \mathrm{~Hz}$ or $1-32 \mathrm{~Hz})$ was performed and then discarded. After washing the tissues a control FRC was performed. If the contractile responses were not consistent ( $>10 \%$ variation) tissues were discarded. Eight tissues were simultaneously tested with at least one time control tissue per experiment. The responses to EFS in vehicle-treated tissues remained stable throughout the period of the experiment.

In a first set of experiments in guinea pig airways, epinastine $(1-100 \mu \mathrm{M})$ was added to the organ baths, with only one concentration of drug added per tissue. After an incubation period of $15 \mathrm{~min}$, a third FRC $(0.5-32 \mathrm{~Hz})$ was obtained.

In a second set of experiments in guinea pig airways, the effects of 5-HT antagonists (methysergide $\left(1 \mu \mathrm{M}, 5-\mathrm{HT}_{1 \mathrm{~A}}\right.$ $1 \mathrm{~B} / 1 \mathrm{D} / 2 / 7$ selective). SDZ 216-525 $\left(10 \mu \mathrm{M}, 5-\mathrm{HT}_{1 \mathrm{~A}}\right.$ selective) [13], ketanserin $\left(10 \mu \mathrm{M}, 5-\mathrm{HT}_{2}\right.$ selective $)$, and tropisetron $\left(1 \mu \mathrm{M}, 5-\mathrm{HT}_{3 / 4}\right.$ selective $)$ were studied on the cholinergic contraction as well as on the effects of epinastine $(3-100 \mu \mathrm{M})$ on the cholinergic contraction elicited by EFS $(0.5-32 \mathrm{~Hz})$.

In a third set of experiments the authors investigated the effects of phentolamine ( $10 \mu \mathrm{M}$; an $\alpha$-adrenergic antagonist) on the cholinergic contraction and on the effects of epinastine $(30-100 \mu \mathrm{M})$ on the cholinergic contraction in guinea pig airways in vitro.

In another set of experiments, guinea pig airway strips were incubated with capsaicin $(10 \mathrm{mM}) 1 \mathrm{~h}$ before the start of the experiment, which was washed out $30 \mathrm{~min}$ later, to deplete the sensory nerves of endogenous tachykinins [14]. Subsequently, the effects of epinastine $(30-100 \mu \mathrm{M})$ on the cholinergic contraction were investigated. The same protocol was used as above. Control tissues were treated with capsaicin only. A second addition of capsaicin (10 $\mu \mathrm{M})$ did not produce any contraction, which confirms the depletion of neuropeptides.

In human airways the effects of epinastine $(30-100 \mu \mathrm{M})$ on the cholinergic contraction elicited by EFS (1-32 Hz) were investigated, both in the presence and in the absence of methysergide $(30 \mu \mathrm{M})$.

Cumulative concentration-response curve to acetylcholine. To determine whether the effects of epinastine on the cholinergic contraction were due to activation of preor postjunctional receptors, the effects of a $15 \mathrm{~min}$ incubation period with epinastine $(100 \mu \mathrm{M})$, were studied on the cumulative-concentration response relationship to exogenously applied ACh in guinea pig and human airways in vitro. A cumulative concentration-response curve to $\mathrm{ACh}$ was performed by adding incremental concentrations, spaced at half $\log _{10}$ intervals $(10 \mathrm{nM}-30 \mathrm{mM})$, to the organ baths. The results were expressed as a percentage of the maximum contraction to ACh $(10 \mathrm{mM})$, which was determined at the beginning of the experiment. 
Measurement of binding to the human 5-hydroxytryptamine receptor

Although epinastine has been shown to bind the rat 5$\mathrm{HT}_{7}$ receptor [7], there was no data available on the affinity of epinastine for the human $5-\mathrm{HT}_{7}$ receptor. The $5-\mathrm{HT}_{7}$ receptor can exist in at least four alternative splice variants. The $5-\mathrm{HT}_{7(\mathrm{a})}$ and $5-\mathrm{HT}_{7(\mathrm{~b})}$ variants seem to be widely distributed, but the $5-\mathrm{HT}_{7(\mathrm{c})}$ receptor variant is believed only to occur in rats and the 5- $\mathrm{HT}_{7(\mathrm{~d})}$ receptor variant is believed only to occur in humans [15].

Therefore the affinity of epinastine for the human receptor was also tested in vitro. Scintillation proximity assay was used to assess inhibition by different epinastine concentrations of the binding of $0.75 \mathrm{nM} 5$-carboxamido[3H]tryptamine (TRK 1038; Amersham Pharmacia Biotech, Roosendaal, the Netherlands) to a recombinant human $5-\mathrm{HT}_{7}$ receptor expressed in HEK-293 cells (RBH57 (Genbank accession No. L21196); Receptor Biology, Baltimore, MD, USA). The membrane was bound to wheat germ agglutinin-coated polyvinyltoluene staphylococcal protein A (SPA) beads, and ligand binding was measured after $2 \mathrm{~h}$ using as assay buffer $50 \mathrm{mM}$ tris-hydroxymethylamino methane (Tris), $10 \mathrm{mM} \mathrm{MgCl}, 0.5 \mathrm{mM}$ ethylenediamine tetraacetic acid (EDTA) and 1\% ascorbic acid, $\mathrm{pH}$ 7.4. Nonspecific binding was assessed in the presence of $10 \mu \mathrm{M}$ unlabelled 5-carboxamidotryptamine. The 50\% inhibitory concentration for displacement of radiolabelled ligand was estimated by extrapolation, and $\mathrm{Ki}$ values calculated after correction for the radioligand occupancy shift using the program Easy-Fit (Boehringer, Germany) [16].

\section{Drugs}

The drugs used in these experiments were obtained from the following sources: epinastine (a kind gift from Boehringer Ingelheim KG, Ingelheim am Rhein, Germany); ketanserin, capsaicin, hexamethonium, tetrodotoxin (Biomol, Sanver Tech, Boechout, Belgium); SDZ 216-525, methysergide, tropisetron (ICS205-930) (a kind gift from Sandoz-Novartis Pharma, Basel, Switzerland); ACh, indomethacin(Sigma ChemicalCo., Eupen, Belgium). Tropisetron and SDZ 216-525 were dissolved in dimethylsulphoxide, capsaicin was dissolved in ethanol. All other drugs were dissolved in distilled water. Control tissues were treated with an equivalent amount of the appropriate solvent. Fresh drug solutions were made up daily. Drug additions did not exceed $1 \%$ (volume/volume) of the organ bath volume. All concentrations refer to the final organ bath concentration.

\section{Analysis of results}

Results are expressed as mean \pm SEM. All contractile responses were measured as the difference between peak tension that developed and resting tension. The effects of a single concentration of epinastine with or without antagonist were expressed as a percentage inhibition, comparing the contractile responses at each stimulation frequency after pretreatment with the contraction at the same frequency in the control response. In most experiments using EFS, where each tissue acted as its own control, results before and after a single concentration drug addition were compared by a Students two-tailed t-test for paired data. Significance between tissues treated with different concentrations of epinastine at different frequencies of stimulation, with or without antagonists was assessed using analysis of variance (ANOVA). When significance was reached, the difference between the results at each concentration or at each frequency of stimulation was assessed by appropriate post hoc tests corrected for multiple comparisons (Newman-Keuls multiple comparisons test).

In experiments involving the effect of epinastine on frequency-response curves, results were also compared using a two-way analysis of variance, in order to test for significant interaction. The two variables were the frequency of stimulation and the concentration of epinastine or the absence or presence of an antagonist.

The same tests were used to assess the effects of epinastine versus control on the cumulative concentrationresponse curve to exogenous ACh. Probability values of $<0.05$ were considered significant.

\section{Results}

\section{Electrical field stimulation}

Effects of epinastine on the cholinergic contraction in guinea pig airways in vitro. EFS in guinea pig airways resulted in a cholinergic contraction. When the mean results are expressed as a percentage of the maximal contraction at $32 \mathrm{~Hz}$, it is evident that the amplitude of the cholinergic contraction increases with increasing frequencies of stimulation. A typical trace is shown in figure 1, which also demonstrates the inhibitory effects of epinastine $(30 \mu \mathrm{M})$ on the cholinergic responses, after an incubation period of $15 \mathrm{~min}$. Preliminary experiments involving a time course of the inhibitory effects of epinastine demonstrated no further inhibition of the cholinergic contraction with longer incubation time. Epinastine $(30 \mu \mathrm{M})$ inhibited the cholinergic contraction at all frequencies of stimulation.

Epinastine $(1-100 \mu \mathrm{M})$ produced a concentration-dependent inhibition of the cholinergic contraction in guinea pig airways with a maximum inhibition of $97 \pm 2 \%$ at $32 \mathrm{~Hz}$ $(\mathrm{n} \geq 5, \mathrm{p}<0.001$ compared to control) (table 1, fig. 2). The frequency of stimulation did not significantly affect the inhibitory effect of epinastine on the cholinergic contraction (two-way ANOVA)

Effects of 5-hydroxytryptamine antagonists on the epinastine-induced inhibition of the cholinergic contraction in guinea pig airways in vitro. Addition of methysergide (1 $\mu \mathrm{M}$, a $5-\mathrm{HT}_{1 / 2 / 7}$ antagonist) had no effect on the EFSinduced cholinergic contraction on its own (fig. 3). However, methysergide $(1 \mu \mathrm{M})$ significantly attenuated the epinastine induced $(30 \mu \mathrm{M})$ inhibition of the cholinergic contraction especially at the lower stimulation frequencies $(0.5-8 \mathrm{~Hz}, \mathrm{n} \geq 5, \mathrm{p}<0.01$ compared to epinastine alone) (fig. 3). Analysis of results by means of twoway ANOVA confirmed that there was no significant interaction between the effect of methysergide and the frequency of stimulation.

SDZ 216-525 (10 $\mu \mathrm{M}$, a 5- $\mathrm{HT}_{1 \mathrm{~A}}$ antagonist) did not affect the cholinergic contraction produced by EFS (data not shown). Moreover, this antagonist failed to prevent the 


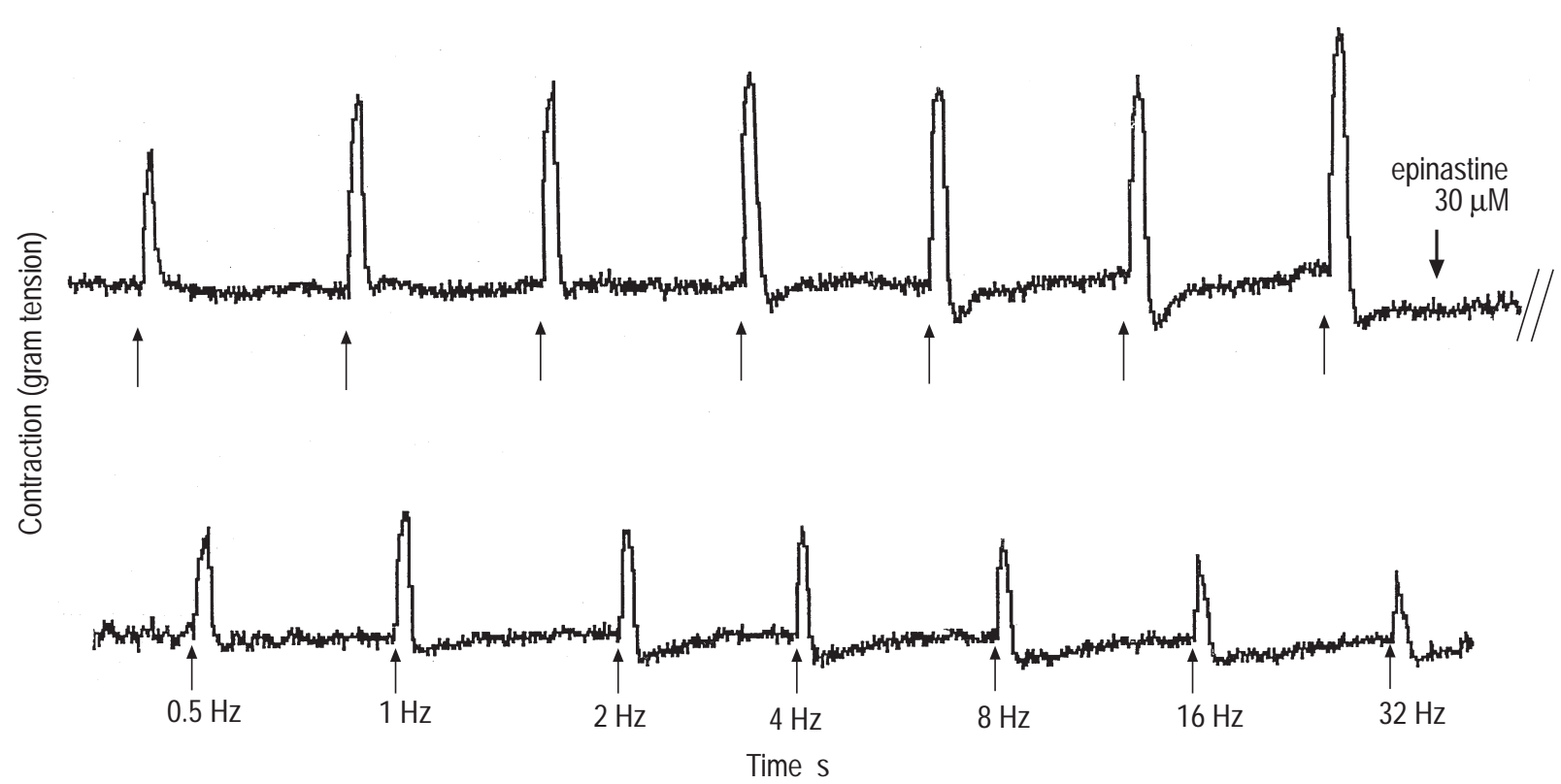

Fig. 1. - Trace showing the inhibitory effects of epinastine $(30 \mu \mathrm{M})$ on the cholinergic contraction, elicited by electrical field stimulation (EFS) $(50 \mathrm{~V}$ at source, $0.5 \mathrm{~ms}, 0.5-32 \mathrm{~Hz}$ for $15 \mathrm{~s}$ every $4 \mathrm{~min}$ ) in guinea pig airway strips in vitro. Epinastine produced a potent inhibition of the cholinergic contraction.

inhibition of the cholinergic contraction by epinastine (30 $\mu \mathrm{M})$ ( $\geq 5$ ) (fig. 3).

Ketanserin $\left(10 \mu \mathrm{M}\right.$, a $5-\mathrm{HT}_{2}$ antagonist), and tropisetron ( $1 \mathrm{mM}$; a 5-HT $\mathrm{HT}_{3 / 4}$ antagonist), had themselves no effect on the cholinergic contraction. They also had no effect on the inhibitory effects of epinastine $(30-100 \mu \mathrm{M})$ on the cholinergic contraction $(n=5$, data not shown).

Effects of phentolamine on the epinastine-induced inhibition of the cholinergic contraction in guinea pig airways in vitro. Addition of phentolamine $(10 \mu \mathrm{M})$, a competitive $\alpha$-adrenergic antagonist had no effect on the EFS-induced cholinergic contraction on its own nor on the epinastine-induced $(30 \mu \mathrm{M})$ inhibition of the cholinergic contraction $(\mathrm{n}=5$, data not shown).

Effects of capsaicin pretreatment on the epinastine-induced inhibition of the cholinergic contraction in guinea pig airways in vitro. Pretreatment of the tissues with capsaicin $(10 \mu \mathrm{M})$, which depletes the sensory nerves of endogenous tachykinins, did not modulate the inhibitory effects of epinastine $(30-100 \mu \mathrm{M})$ on the EFS-induced cholinergic contraction in guinea pig airways in vitro $(\mathrm{n}=5$, data not shown).

Effects of terfenadine on the cholinergic contraction in guinea pig airways. Terfenadine $(10-100 \mu \mathrm{M})$, another $\mathrm{H}_{1}$ receptor antagonist, failed to produce a significant inhibition of the cholinergic contraction in guinea pig airways in vitro $(\mathrm{n}=5$, data not shown).

Effects of epinastine on the cholinergic contraction in human airways in vitro. EFS in human airways resulted in a cholinergic contraction which increased in amplitude with increasing frequencies of stimulation (table 2). Epinastine $(30-100 \mu \mathrm{M})$ inhibited the cholinergic contraction with a maximum inhibition of $36 \pm 5 \%$ at $32 \mathrm{~Hz}$ $(n \geq 5, p<0.01$ compared to control). The frequency of stimulation did not significantly affect the inhibitory effect of epinastine on the cholinergic contraction (twoway ANOVA). Pretreatment with methysergide $(30 \mu \mathrm{M})$ had no effect on the cholinergic contraction but significantly attenuated the inhibitory effects of epinastine $(100 \mu \mathrm{M})$ on the cholinergic contraction in human airways only at lower stimulation frequencies $(1-4 \mathrm{~Hz})$ $(\mathrm{n} \geq 5, \mathrm{p}<0.05$ compared to control) (fig. 4). Analysis of results by means of two-way ANOVA confirmed that there was no significant interaction between the effect of methysergide and the frequency of stimulation.

\section{Concentration-response curve to acetylcholine}

Effects of epinastine on the concentration-response curve to acetylcholine in guinea pig airways in vitro. Acetylcholine produced a concentration-dependent contraction in guinea pig tracheal strips with a maximal contraction of $1.9 \pm 0.3 \mathrm{~g}$ tension at a concentration of $10 \mathrm{mM} \mathrm{ACh}$. Pretreatment with epinastine $(100 \mu \mathrm{M})$ did not significantly alter the contractile responses to incremental concentrations of acetylcholine $(10 \mathrm{nM}-30 \mathrm{mM})$ in guinea pig airways in vitro $(\mathrm{n}=5)$ (fig. 5a)

Effects of epinastine on the concentration-response curve to acetylcholine in human airways in vitro. ACh produced a concentration-dependent contraction in human bronchial rings with a maximal contraction of $2.2 \pm 0.3 \mathrm{~g}$ tension at a concentration of $10 \mathrm{mM} \mathrm{ACh}$. Pretreatment with epinastine $(100 \mu \mathrm{M})$ had no significant effect on the contractile responses to incremental concentrations of ACh $(10 \mathrm{nM}-30 \mathrm{mM})$ in human airways in vitro $(\mathrm{n}=5)$ (fig. 5b).

Measurement of binding to the human 5-hydroxytryptamine 7 receptor. The $\mathrm{Ki}$ (affinity constant) for epinastine hydrochloride racemate was $6.9 \pm 2.7 \mathrm{nM}$ (mean $\pm \mathrm{SD}$, 
Table 1. - The effect of epinastine (Epi) (1-100 $\mu \mathrm{M}$ ) on the electrical field stimulation (EFS)-induced contractile responses at different frequencies of stimulation in guinea pig airways in vitro

\begin{tabular}{|c|c|c|c|c|c|c|c|c|c|c|c|c|c|c|}
\hline & \multicolumn{14}{|c|}{ Frequency of stimulation } \\
\hline & \multicolumn{2}{|c|}{$0.5 \mathrm{~Hz}$} & \multicolumn{2}{|c|}{$1 \mathrm{~Hz}$} & \multicolumn{2}{|c|}{$2 \mathrm{~Hz}$} & \multicolumn{2}{|c|}{$4 \mathrm{~Hz}$} & \multicolumn{2}{|c|}{$8 \mathrm{~Hz}$} & \multicolumn{2}{|c|}{$16 \mathrm{~Hz}$} & \multicolumn{2}{|c|}{$32 \mathrm{~Hz}$} \\
\hline & Pre & Post & Pre & Post & Pre & Post & Pre & Post & Pre & Post & Pre & Post & Pre & Post \\
\hline $\begin{array}{l}\text { Epi } \\
100 \mu \mathrm{m}\end{array}$ & $\begin{array}{c}36.2 \\
(6.1)\end{array}$ & $\begin{array}{c}7.6 \\
(4.7)^{+}\end{array}$ & $\begin{array}{l}55.1 \\
(8.1)\end{array}$ & $\begin{array}{c}8.5 \\
(4.7)^{+}\end{array}$ & $\begin{array}{l}59.4 \\
(6.7)\end{array}$ & $\begin{array}{c}7.0 \\
(3.8)^{+}\end{array}$ & $\begin{array}{l}67.7 \\
(5.1)\end{array}$ & $\begin{array}{c}6.0 \\
(3.0)^{+}\end{array}$ & $\begin{array}{l}70.2 \\
(5.7)\end{array}$ & $\begin{array}{l}4.4 \\
(2.6)^{+}\end{array}$ & $\begin{array}{l}80.1 \\
(3.3)\end{array}$ & $\begin{array}{l}2.6 \\
(2.1)^{+}\end{array}$ & 100 & $\begin{array}{l}2.1 \\
(1.7)^{+}\end{array}$ \\
\hline $\begin{array}{l}\text { Epi } \\
30 \mu \mathrm{m}\end{array}$ & $\begin{array}{l}50.0 \\
(4.3)\end{array}$ & $\begin{array}{l}38.7 \\
(3.5)^{+}\end{array}$ & $\begin{array}{c}64.5 \\
(5.1)\end{array}$ & $\begin{array}{l}46.2 \\
(4.1)^{+}\end{array}$ & $\begin{array}{l}67.0 \\
(5.9)\end{array}$ & $\begin{array}{l}46.7 \\
(4.2)^{+}\end{array}$ & $\begin{array}{l}72.5 \\
(6.4)\end{array}$ & $\begin{array}{l}46.4 \\
(2.7)^{+}\end{array}$ & $\begin{array}{l}71.1 \\
(6.5)\end{array}$ & $\begin{array}{l}42.5 \\
(2.9)^{+}\end{array}$ & $\begin{array}{l}78.4 \\
(4.6)\end{array}$ & $\begin{array}{l}42.7 \\
(4.4)^{+}\end{array}$ & 100 & $\begin{array}{c}47.1 \\
(3.5)^{+}\end{array}$ \\
\hline $\begin{array}{l}\text { Epi } \\
10 \mu \mathrm{m}\end{array}$ & $\begin{array}{l}46.6 \\
(2.4)\end{array}$ & $\begin{array}{c}43.2 \\
(4.6)\end{array}$ & $\begin{array}{l}67.3 \\
(2.2)\end{array}$ & $\begin{array}{l}56.5 \\
(3.3)^{*}\end{array}$ & $\begin{array}{l}73.0 \\
(3.0)\end{array}$ & $\begin{array}{l}58.2 \\
(4.7)^{*}\end{array}$ & $\begin{array}{l}78.6 \\
(3.2)\end{array}$ & $\begin{array}{l}61.4 \\
(5.1)^{* *}\end{array}$ & $\begin{array}{l}78.7 \\
(3.9)\end{array}$ & $\begin{array}{l}66.1 \\
(4.0)\end{array}$ & $\begin{array}{l}81.8 \\
(4.1)\end{array}$ & $\begin{array}{l}66.3 \\
(3.7)^{*}\end{array}$ & 100 & $\begin{array}{l}74.7 \\
(4.3)^{*}\end{array}$ \\
\hline $\begin{array}{l}\text { Epi } \\
1 \mu \mathrm{m}\end{array}$ & $\begin{array}{l}47.4 \\
(3.9)\end{array}$ & $\begin{array}{l}47.5 \\
(4.2)\end{array}$ & $\begin{array}{l}68.5 \\
(4.6)\end{array}$ & $\begin{array}{l}61.6 \\
(3.7)\end{array}$ & $\begin{array}{l}64.1 \\
(5.6)\end{array}$ & $\begin{array}{l}56.2 \\
(6.2)\end{array}$ & $\begin{array}{l}76.0 \\
(4.5)\end{array}$ & $\begin{array}{l}64.4 \\
(5.3)\end{array}$ & $\begin{array}{l}78.9 \\
(4.3)\end{array}$ & $\begin{array}{l}62.0 \\
(3.7)\end{array}$ & $\begin{array}{l}78.6 \\
(4.4)\end{array}$ & $\begin{array}{l}66.1 \\
(3.9)\end{array}$ & 100 & $\begin{array}{c}88.4 \\
(2.3)\end{array}$ \\
\hline Control & $\begin{array}{l}45.6 \\
(5.2)\end{array}$ & $\begin{array}{c}45.4 \\
(4.3)\end{array}$ & $\begin{array}{l}56.6 \\
(4.5)\end{array}$ & $\begin{array}{l}57.1 \\
(6.7)\end{array}$ & $\begin{array}{l}59.2 \\
(5.8)\end{array}$ & $\begin{array}{l}63.4 \\
(4.1)\end{array}$ & $\begin{array}{l}63.2 \\
(2.4)\end{array}$ & $\begin{array}{l}68.4 \\
(3.8)\end{array}$ & $\begin{array}{l}67.7 \\
(2.8)\end{array}$ & $\begin{array}{l}66.9 \\
(3.2)\end{array}$ & $\begin{array}{l}77.5 \\
(4.5)\end{array}$ & $\begin{array}{l}80.4 \\
(2.7)\end{array}$ & 100 & $\begin{array}{l}95.7 \\
(2.8)\end{array}$ \\
\hline
\end{tabular}

Both baseline frequency response curve (Pre) as well as frequency response curve after incubation with epinastine (Post) are expressed as a percentage of the maximal cholinergic contraction to EFS at $32 \mathrm{~Hz}$ with SEM in parentheses. Significance of inhibition. *: $\mathrm{p}<0.05 ; * *: \mathrm{p}<0.01 ;{ }^{+}: \mathrm{p}<0.001$, compared to control.

$\mathrm{n}=3$ ). In the same system the $\mathrm{Kd}$ (dissociation constant) of the $5-\mathrm{HT}_{7}$ agonist 5 -carboxamidotryptamine was $0.6 \mathrm{nM}$, and the $\mathrm{Ki}$ of the $5-\mathrm{HT}_{7}$ antagonist lisuride hydrogen maleate was $0.4 \mathrm{nM}$.

\section{Discussion}

The aim of the present study was to investigate the effects of epinastine on the EFS-induced cholinergic contraction in vitro in both guinea pig and human airways. Epinastine produced a concentration-dependent inhibition of the cholinergic contraction in guinea pig airways and in human airways. Epinastine did not affect the response to exogenously applied ACh in guinea pig and human airways in vitro, which exludes a postjunctional mechanism of action and suggests that epinastine interacts with presynaptic (prejunctional) receptors on cholinergic postganglionic nerves to inhibit the release of ACh induced by EFS.

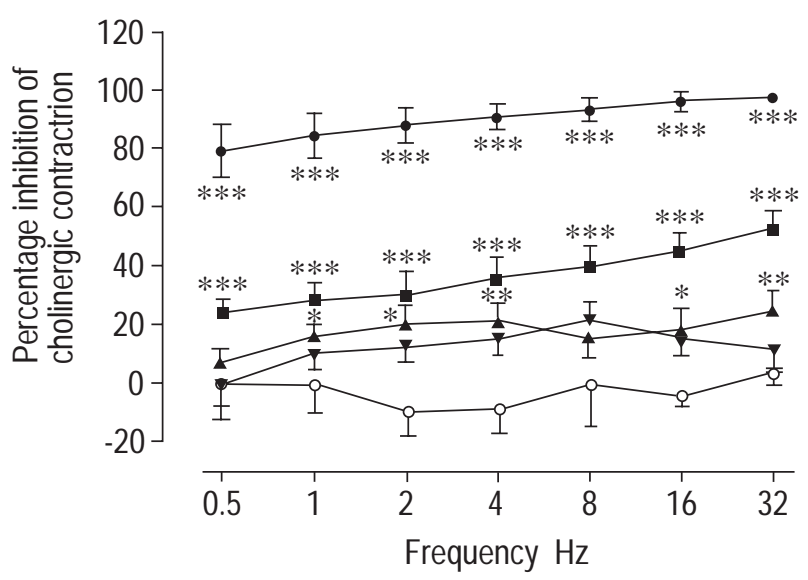

Fig. 2. - The effects of epinastine $(1-100 \mu \mathrm{M})$ on the cholinergic contraction, elicited by electrical field stimulation (EFS) (50 V at source, $0.5 \mathrm{~ms}, 0.5-32 \mathrm{~Hz}$ for $15 \mathrm{~s}$ every $4 \mathrm{~min}$ ) in guinea pig airway in vitro. Epinastine produced a concentration-dependent inhibition of the choinergic contraction. Curves are shown for epinastine $100 \mu \mathrm{M}(\mathbf{O})$, epinastine $30 \mu \mathrm{M}(\boldsymbol{\square})$, epinastine $10 \mu \mathrm{M}(\boldsymbol{\Delta})$, epinastine $1 \mu \mathrm{M}(\boldsymbol{\nabla})$ versus control $(O)$. Points represent mean \pm SEM of at least $n=5$ observations. Significance of inhibition: *: $\mathrm{p}<0.05 ; * *: \mathrm{p}<0.01 ; * * * \mathrm{p}<0.001$, compared to control.
Epinastine is a drug with $\mathrm{H}_{1}$ receptor blocking effects [3], which has been put forward as a potentially valuable tool in the treatment of allergic disorders. Administration of epinastine protected against the bronchoconstriction induced by 5-HT [4]. Recently, the authors have shown that epinastine inhibited the release of neuropeptides in guinea pig airways in vitro through stimulation of a prejunctional 5-HT receptor [8]. There is also in vivo evidence for a prejunctional effect of epinastine on electrically stimulated (cholinergic) bronchoconstriction [17] which supports the present findings of an inhibitory effect on EFS-induced contraction in vitro.

Several agonists inhibit the cholinergic contraction in vitro and in vivo by a mechanism that involves prejunctional receptors on postganglionic cholinergic nerve endings. Inhibitory receptors which have been characterized in guinea pig and human airways include muscarinic $\mathrm{M}_{2}$

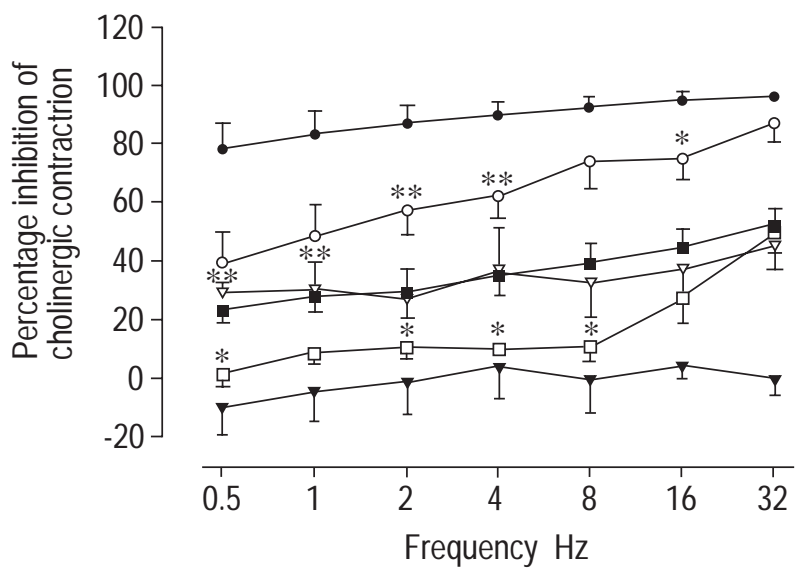

Fig. 3. - Inhibitory effects of epinastine $100 \mu \mathrm{M}(\mathbf{O})$ and $30 \mu \mathrm{M}(\boldsymbol{\square})$ on the cholinergic contraction, elicited by electrical field stimulation (EFS) ( $50 \mathrm{~V}$ at source, $0.5 \mathrm{~ms}, 0.5-32 \mathrm{~Hz}$ for $15 \mathrm{~s}$ every $4 \mathrm{~min}$ ) in guinea pig airway strips in vitro, and attenuation by methysergide $1 \mu \mathrm{M}$ of the inhibitory effect of epinastine $100 \mu \mathrm{M}(\mathrm{O})$ and $30 \mu \mathrm{M}(\square)$. Methysergide $1 \mu \mathrm{M}$ by itself $(\boldsymbol{\nabla})$ had no effect on the cholinergic contraction in guinea pig airways in vitro. Pretreatment with SDZ 216-525 $1 \mu \mathrm{M}(\nabla)$ did not modulate the inhibition of the cholinergic contraction by epinastine $30 \mu \mathrm{M}$. Points represent mean \pm SEM of at least $n=5$ observations. Significance of inhibition: $*: \mathrm{p}<0.05 ; * *: \mathrm{p}<0.01$, compared to epinastine $100 \mu \mathrm{M}$ or epinastine $30 \mu \mathrm{M}$. 
Table 2. - The effect of epinastine (Epi) $(30-100 \mu \mathrm{M})$ on the electrical field stimulation (EFS)-induced contractile responses at different frequencies of stimulation in human airways in vitro

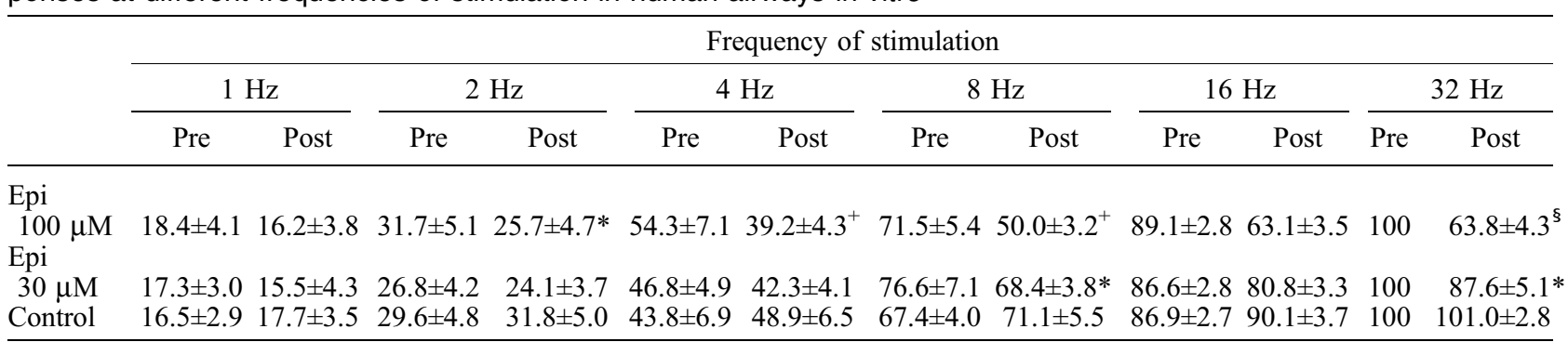

Both baseline frequency response curve (Pre) as well as frequency response curve after incubation with epinastine (Post) are expressed as a percentage of the maximal cholinergic contraction to EFS at $32 \mathrm{~Hz} \pm$ SEM. Significance of inhibition. $*: p<0.05 ;{ }^{+}: p<0.01 ;{ }^{\S}: p<0.001$, compared to control.

receptors, adrenergic $\alpha_{2}$ and $\beta_{2}$ receptors, opioid receptors, $\mathrm{H}_{3}$ receptors and receptors for vasoactive intestinal peptide (VIP), neuropeptide $\mathrm{Y}$ and prostaglandin $(\mathrm{PG}) \mathrm{E}_{2}[1]$. In the present study, the authors have also tried to further elucidate the prejunctional receptor responsible for the inhibitory effects of epinastine on the cholinergic contraction, by using selective antagonists.

Terfenadine, an $\mathrm{H}_{1}$ receptor antagonist, did not produce any inhibition of the cholinergic contraction in guinea pig airways, which virtually excludes the possibility of prejunctional $\mathrm{H}_{1}$ receptor involvement as a mechanism of action in the inhibition of the cholinergic contraction.

Epinastine has some binding affinity at $\alpha$-adrenergic receptors and adrenergic agonists modulate the cholinergic contraction in guinea pig airways [1]. Phentolamine, an $\alpha$-adrenergic receptor antagonist failed, however, to prevent the inhibition produced by epinastine, which also excludes $\alpha$-adrenergic agonistic activity as the possible mechanism of action of epinastine in inhibiting the cholinergic contractile responses.

It has been well established that 5-HT agonists modulate the cholinergic contraction in isolated airways in vitro [18-21]. Epinastine has an affinity at several 5-HT receptors $[3,7]$, and has been shown to act both as a $5-\mathrm{HT}$

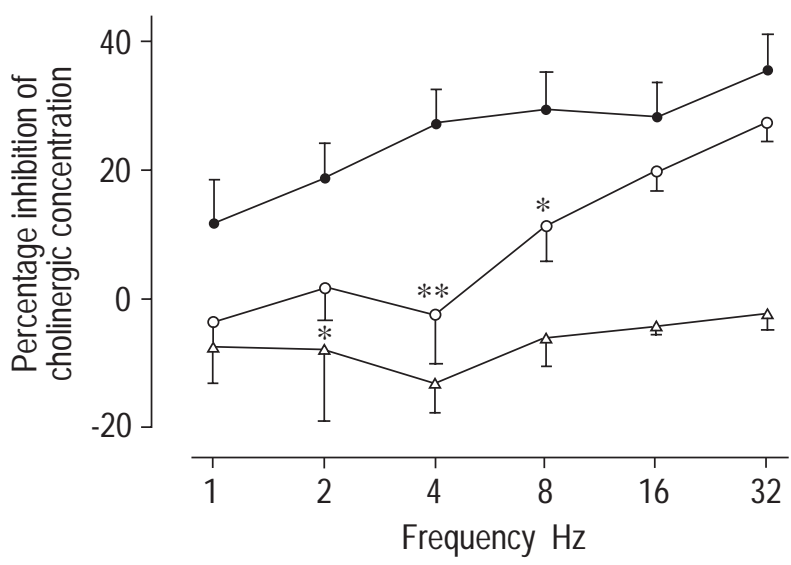

Fig. 4. - Inhibitory effects of epinastine $100 \mu \mathrm{M}(\mathbf{O})$ on the cholinergic contraction, elicited by electrical field stimulation (EFS) (50 V at source, $0.5 \mathrm{~ms}, 1-32 \mathrm{~Hz}$ for $15 \mathrm{~s}$ every $4 \mathrm{~min}$ ) in human airway strips in vitro, and attenuation of this inhibition by methysergide $30 \mu \mathrm{M}(\mathrm{O})$. Methysergide $30 \mu \mathrm{M}$ by itself $(\triangle)$ had no effect on the cholinergic contraction in human airways in vitro. Points represent mean \pm SEM of at least $n=5$ observations. Significance of inhibition: *: $\mathrm{p}<0.05$; **: $\mathrm{p}<0.01$, compared to epinastine $(30 \mu \mathrm{M})$. antagonist [4] as well as a 5-HT agonist [8]. This suggests that an effect through stimulation of 5-HT receptors could feature as an explanation for its effects on the cholinergic contraction. The inhibitory effects of epinastine in the current experiments could not be blocked by ketanserin, a $5-\mathrm{HT}_{2}$ antagonist, nor by tropisetron, a $5-\mathrm{HT}_{3,4}$ antagonist, nor by SDZ 216-525, a 5-HT $1 \mathrm{~A}$ antagonist. Methysergide, an antagonist at $5-\mathrm{HT}_{1 / 2 / 7}$ receptors, however, at a concentration that had no effect on the cholinergic contraction on its own, significantly attenuated the inhibitory effects of epinastine on the EFS-induced cholinergic contraction of guinea pig tracheal strips and human bronchial rings. These results suggest the
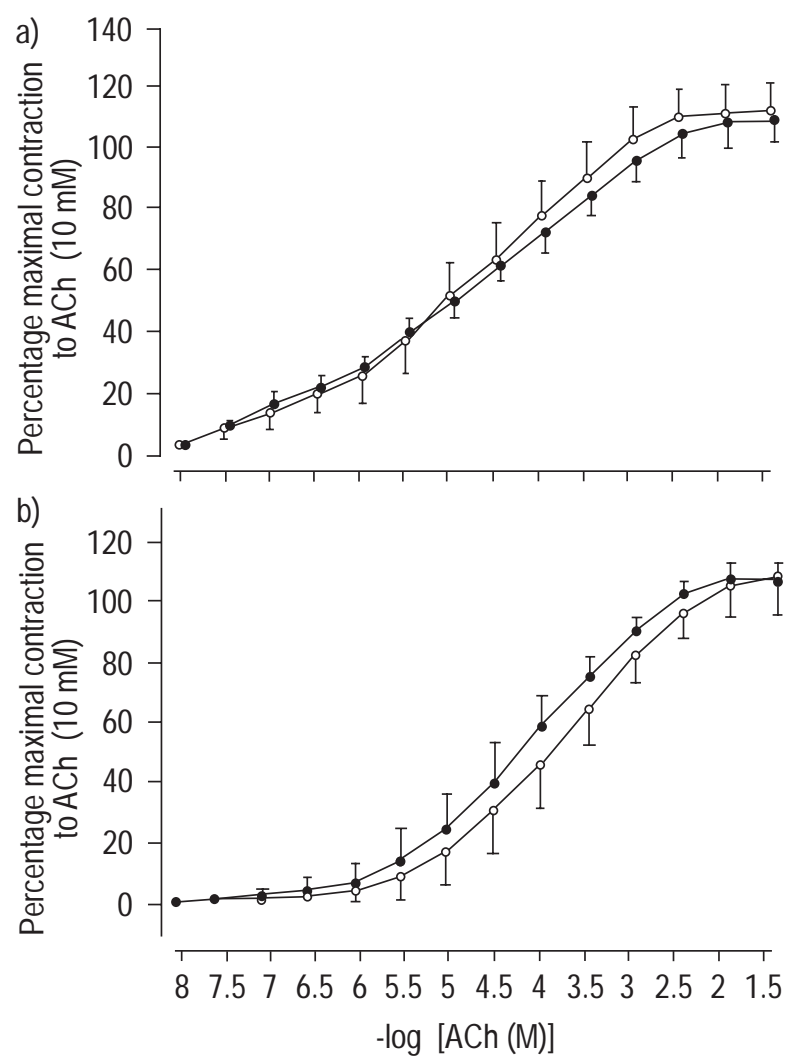

Fig. 5. - Effects of epinastine $100 \mathrm{mM}$ on the cumulative concentrationresponse curve to exogenously applied acetylcholine (ACh) $(10 \mu \mathrm{M})$. Curves are shown for ACh in the absence $(O)$ and in the presence $(\mathcal{)})$ of epinastine $100 \mu \mathrm{M}$. Points represent mean \pm SEM of at least $n=5$ observations. 
involvement of a $5-\mathrm{HT}_{7}$ receptor in the inhibition of the cholinergic contraction by epinastine and are consistent with previous observations regarding the inhibitory effect of 8-hydroxy-2-(di-n-propyl-amino)tetralin (8-OHDPAT), another $5-\mathrm{HT}_{7}$ agonist, on the cholinergic contraction in guinea pig and human airways in vitro [11]. Receptor binding studies have clearly shown the ability of epinastine to bind $5-\mathrm{HT}_{7}$ receptors and the absence of binding affinities at 5-MT 1 receptors in rats [7].

In the present study the authors have confirmed the affinity of epinastine for human $5-\mathrm{HT}_{7}$ receptors. The pharmacological profile of a $5-\mathrm{HT}_{7}$ receptor also fits the profile of the prejunctional 5 - $\mathrm{HT}_{1}$-like receptor on sensory nerve endings. Activation of this receptor has accounted for the ability of epinastine to inhibit the NANC contraction in guinea pig airways in vitro [8]. Furthermore, it has recently been demonstrated that $8-\mathrm{OH}-\mathrm{DPAT}$ and, to a lesser extent 5-carboxamidotryptamine are able to inhibit the cholinergic contraction in guinea pig and human airways. As methysergide was able to prevent these inhibitory effects of 8-OH-DPAT on the cholinergic contractile responses while SDZ 216-525 had no effect, it was suspected that an inhibitory 5-HT receptor was present, located on postganglionic cholinergic nerves [11]. Due to the lack of selective agonists and antagonists, the exact 5HT receptor subtype could not be identified, but activation of a $5-\mathrm{HT}_{7}$ subtype receptor was hypothesized to account for the effects of 8-OH-DPAT [11]. The findings on the effects of epinastine on the cholinergic contraction, however, corroborate the hypothesis of the presence of an inhibitory $5-\mathrm{HT}_{7}$ receptor on cholinergic nerve endings. The effect of methysergide on the inhibitory effect of epinastine was more pronouced at the lower frequencies of stimulation. The effect of epinastine at higher frequencies of stimulation could not be completely prevented, which might suggest that epinastine also inhibits the cholinergic contraction by an additional mechanism of action.

It could also be argued that epinastine might modulate the cholinergic contraction in guinea pig airways in vitro by inhibitory effects on the release of neuropeptides. Sensory neuropeptides released from C-fibres may facilitate cholinergic neurotransmission [22] and epinastine has been found to inhibit the NANC contraction, mediated by the release of neuropeptides from C-fibres, in guinea pig airways in vitro [8]. This is unlikely to be the explanation, however, since epinastine also inhibited the cholinergic contraction in guinea pig tracheal segments pretreated with capsaicin, which depletes the sensory nerves of endogenous tachykinins. It also seems unlikely that epinastine was able to modulate the cholinergic contraction by stimulating the inhibitory NANC (iNANC) relaxation. VIP and NO, both implicated as neurotransmitters of the iNANC relaxation, have been demonstrated to be able to modulate the cholinergic neurotransmission in guinea pig tracheal strips and human tracheal strips $[23,24]$. This seems very unlikely as it has previously been shown that 8-OH-DPAT did not modulate the iNANC relaxation in guinea pig airways [11].

Preliminary clinical studies with epinastine suggest a significant improvement in asthma symptom control [25]. As the efficacy of selective histamine $\mathrm{H}_{1}$ antagonists in the treatment of asthma has not been established [26], it seems logical to assume that other mechanisms of action account for the prophylactic effects of epinastine. The authors have shown in this study that epinastine is able to inhibit the cholinergic contraction by stimulation of a prejunctional 5-hydroxytryptamine receptor, probably a 5-hydroxytryptamine ${ }_{7}$ subtype receptor, although relatively high concentrations of epinastine were required to obtain a statistically significant effect. Furthermore, the discriminative binding affinities of epinastine, which binds the rat and human 5-hydroxytryptamine ${ }_{7}$ receptors but not the 5-hydroxytryptamine ${ }_{1}$ subtype receptors [7] in contrast to other known 5-hydroxytryptamine ${ }_{7}$ agonists such as 8-hydroxy-2-(di-n-propyl-amino)tetralin and 5-carboxamidotryptamine, also suggest that epinastine could be a valuable pharmacological tool in identifying 5-hydroxytryptamine7-mediated effects.

\section{References}

1. Barnes PJ. Modulation of neurotransmission in airways. Physiol Rev 1992; 72: 699-729.

2. Adamus WS, Oldigs-Kerber J, Lohmann HF. Antihistamine activity and central effects of WAL $801 \mathrm{CL}$ in man. Eur J Clin Pharmacol 1987; 33: 381-385.

3. Fugner A, Bechtel WD, Kuhn FJ, Mierau J. In vitro and in vivo studies of the non-sedating antihistamine epinastine. Arzneimittelforschung 1988; 38: 1446-1453.

4. Tasaka K, Kamei C, Nakamura S. Inhibitory effect of epinastine on bronchoconstriction induced by histamine, platelet activating factor and serotonin in guinea pigs and rats. Arzneimittelforschung 1994; 44: 327-329.

5. Misawa M, Kanai Y. Effect of the new antiallergic drug epinastine on chemical mediator induced bronchoconstrictions in guinea pigs. Arzneimittelforschung 1991; 41: 1145-1149.

6. Jackson WR, Copp FC, Cullen JD, et al. Chemical design of peripherally acting compounds. Clin Exp Pharmacol Physiol 1992; 19: 17-23.

7. Meade CJ. The mechanism by which epinastine stops an adenosine analog contracting BDE rat airways. $\mathrm{Am} \mathrm{J}$ Respir Crit Care Med 1998; 157: 522-530.

8. Dupont LJ, Meade CJ, Demedts MG, Verleden GM. Epinastine (WAL 801CL) modulates the noncholinergic contraction in guinea pig airways in vitro by a prejunctional 5-HT1-like receptor. Eur Respir J 1996; 9: 1433-1438.

9. $\quad$ Pype JL, Verleden GM, Demedts MG. 5-HT modulates noncholinergic contraction in guinea pig airways in vitro by prejunctional 5-HT1-like receptor. J Appl Physiol 1994; 77: 1135-1141.

10. Eglen RM, Jasper JR, Chang DJ, Martin GR. The 5-HT7 receptor: orphan found. Trends Pharmacol Sci 1997; 18: 104-107.

11. Dupont LJ, Pype JL, Demedts MG, De Leyn P, Deneffe G, Verleden GM. The effect of 8-OH-DPAT on the cholinergic contraction in guinea pig and human airways in vitro. Am J Respir Crit Care Med 1998; 158: 1479-1486.

12. Aikawa T, Sekizawa K, Itabashi S, Sasaki H, Takishima $\mathrm{T}$. Inhibitory actions of prostaglandin E1 on non-adrenergic non-cholinergic contraction in guinea pig bronchi. Br J Pharmacol 1990; 101: 13-14.

13. Schoeftter P, Fozard JR, Stoll A, Siegl H, Seiler MP, Hoyer D. SDZ 216-525, a selective and potent $5-\mathrm{HT}_{1 \mathrm{~A}}$ receptor antagonist. Eur J Pharmacol 1993; 244: 251-257.

14. Lundberg JM, Saria A. Bronchial smooth muscle contraction induced by stimulation of capsaicin-sensitive sensory neurons. Acta Physiol Scand 1982; 116: 473-476. 
15. Heidmann DEA, Metcalf MA, Kohen R, Hamblin MW. Four 5-hydroxytryptamine7 (5-HT7) receptor isoforms in human and rat produced by alternative splicing: species differences due to altered intron- exon organisation. $J$ Neurochem 1997; 68: 1372-1381.

16. Schittkowski K. Parameter estimation in systems of nonlinear equations. Numerische Mathematik 1994; 68: 129 142.

17. Meade CJ. Epinastine can block bronchospasm induced by electrical stimulation of the vagus nerve. Eur Respir $J$ 1993; (Abstract) 6: 316s.

18. Van Oosterhout AJ, Hofman G, Woutersen-Van Nijnanten FM, Nijkamp FP. 5-HT 1 -like receptors mediate potentiation of cholinergic nerve-mediated contraction of isolated mouse trachea. EurJ Pharmacol 1991; 209: 237244.

19. Szarek JL, Zhang JZ, Gruetter CA. 5-HT2 receptors augment cholinergic nerve-mediated contraction of rat bronchi. Eur J Pharmacol 1993; 231: 339-346.

20. Rizzo CA, Kreutner W, Chapman RW. 5-HT 3 receptors augment neuronal, cholinergic contractions in guinea pig trachea. Eur J Pharmacol 1993; 234: 109-112.

21. Dupont LJ, Pype JL, Demedts MG, Verleden GM. 5-HT facilitates the cholinergic contraction in human airways in vitro through stimulation of both $5-\mathrm{HT}_{3}$ and $5-\mathrm{HT}_{4}$ receptors. Am J Respir Crit Care Med 1998; 157: A720.

22. Stretton D, Belvisi MG, Barnes PJ. The effect of sensory nerve depletion on cholinergic neurotransmission in guinea pig airways. J Pharmacol Exp Ther 1992; 260: 1073-1080.

23. Belvisi MG, Miura M, Stretton CD, Barnes PJ. Endogenous VIP and NO modulate cholinergic neurotransmission in guinea pig trachea. Eur J Pharmacol 1993; 231: 97-102.

24. Ward JR, Fox AJ, Miura M, et al. Modulation of cholinergic neural bronchoconstriction by endogenous nitric oxide and vasoactive intestinal peptide in human airways in vitro. J Clin Invest 92: 736-742.

25. Takishima T, Tamura G, Yamauchi K, Miyamoto T, Shida T. Clinical study of WAL 801 CL (epinastine) on adult bronchial asthma: multicenter, double-blind, controlled study versus ketotifen fumarate. J Clin Ther Med 1992; 8: 169-197.

26. Bousquet J, Godard P, Michel FB. Antihistamines in the treatment of asthma. Eur Respir J 1992; 5: 1137-1142. 